\title{
Turkish adaptation of the Physical Activity Readiness Questionare for Everyone (PAR-Q+)
}

\author{
Herkes için Egzersize Hazırbulunuşluk Anketinin (EGZ-A+) Türkçe versiyona uyarlaması \\ Yusuf Haydar Ertekin ${ }^{\text {a }}$ \\ ${ }^{\text {a }}$ Canakkale Onsekiz Mart University, School of Medicine, Department of Family Medicine, Canakkale, Turkey
}

\begin{abstract}
Introduction: The Physical Activity Readiness Questionnaire for Everyone (PAR-Q+) is one of the tools suggested by the American College of Sports Medicine for health screening before initiating exercise. This study aimed to adapt the PAR-Q+ into Turkish.

Methods: After the Turkish translation, the instrument was applied to a sufficient number of samples from the family medicine outpatient clinics. Simultaneously, socio-demographic features were collected from the participants. The data were evaluated using SPSS package program.

Results: According to the test/retest analysis, the reliability of the instrument was significantly high $(\mathrm{r}=0.87, \mathrm{p}<0.001)$. Mean age \pm standard deviation and body mass index of the participants were $48.0 \pm 16.1$ and $27.9 \pm 5.9$, respectively, with $58.6 \%$ ( $\mathrm{n}=178$ ) being males. Hypertension, diabetes, and smoking frequency were $32.2 \%(\mathrm{n}=98), 26.0 \%(\mathrm{n}=79)$, and $37.8 \%(\mathrm{n}=115)$, respectively.

Conclusion: The high proportion of medical conditions present among the participants suggests its need to be utilized by the community. This study has demonstrated safe usage of the Turkish adaptation of the PAR-Q+ instrument. We believe that this tool should become widely used by family physicians.
\end{abstract}

Keywords: physical activity, validation studies, family physicians, family practice, translations, exercise, surveys and questionnaires, Turkey

\section{ÖZET}

Giriş: Herkes için Egzersize Hazırbulunuşluk Anketi (EGZ-A+), Amerikan Spor Hekimliği Birliğinin egzersize başlamadan önce sağlık taraması için önerdiği araçlardan biridir.

Yöntem: Türkçe çeviriden sonra, aile hekimliği polikliniklerinden yeterli sayıda örnekleme uygulandı. Aynı zamanda katılımcılardan sosyodemografik özellikler toplandı. Veriler SPSS paket programı kullanılarak değerlendirildi.

Bulgular: Test/tekrar test analizine göre, ölçek güvenilirliği önemli derecede yüksekti $(r=0,87, p<0,001)$. Katılımcıların ortalama yaş \pm standart sapma ve vücut kütle indeksi sırasıyla 48,0 $\pm 16,1$ ve 27,9 $\pm 5,9$ iken, \%58,6’sı (n = 178) erkek cinsiyettir. Hipertansiyon, şeker hastalı̆̆ ve sigara içme sıklı̆̆ sırasıyla \%32,2 ( $\mathrm{n}=98), \% 26,0(\mathrm{n}=79)$ ve $\% 37,8(\mathrm{n}=115)$ idi.

Sonuç: Katılımcılar arasında mevcut tıbbi koşulların yüksek oranı, toplum tarafından kullanılmasının gerekliliğini ortaya koymaktadır. Bu çalışma PAR-Q+ ölçeğinin Türkçe uyarlamasını güvenli bir şekilde kullandığını göstermiştir. Bu aracın aile hekimleri tarafından yaygın olarak kullanılması gerektiğine inanıoruz.

Anahtar kelimeler: fiziksel aktivite, geçerlilik çalışması, aile hekimleri, aile hekimliği, çeviriler, egzersiz, anket ve ölçekler, Türkiye

Submission: Feb 16, 2018

Acceptance: Apr 09, 2018

E-Mail: dr.ertekin@gmail.com

Correspondence: Yusuf Haydar Ertekin, MD

Canakkale Onsekiz Mart University, School of Medicine, Department of Family Medicine, Hospital of Terzioglu Campus Entry, Fifth Floor, Canakkale-Turkey 


\section{Introduction}

The World Health Organization (WHO) reports physical activity as the fourth leading risk factor for global mortality. Physical inactivity levels are rising in many countries with significant implications for the prevalence of non-communicable diseases and the general health of the population worldwide. In the communities with low and middle levels of income, national guides for physical activity are limited [1]. However, guidelines on necessary examinations before exercise have been developed. Pre-exercise tests are known to be obligatory in some countries [2,3].

One of the instruments used for pre-exercise assessment is the Physical Activity Readiness Questionnaire for Everyone (PAR-Q+) [4]. The American College of Sports Medicine (ACSM) has referred to this instrument as an evidence-based evaluation tool in 1998. The PAR-Q+ makes suggestions for screenings before exercise implementation [5]. The ACSM has given priority to the detection of cardiovascular, metabolic, and renal diseases within the last one year according to an algorithm in 1998, which was updated in 2015 [6].

The benefits of physical activity are well-known today, and physical activity is suggested and encouraged in Turkey and many developed countries. There are physical exercise activities suitable for individual age and health conditions. However, people with certain chronic diseases, such as diabetes, hypertension, and musculoskeletal diseases should consult a physician regarding their suitable physical activity. The standard PAR-Q+ test is used to define who should be referred to a specialist and who can initiate the exercise without specialist consultation, after filling the test and deciding together with their family doctor. Widespread use, high validity (sensitivity $(0.90(95 \% \mathrm{CI}=0.77-0.96))$ and specificity $(1$ (95\% CI $=0.99-1)$, and reliability $(\mathrm{r}=0.99)$ [7] were taken into consideration when selecting the PAR-Q+ test. This study aimed to adopt the PAR-Q+ screening tool into Turkish.

\section{Methods}

\section{Study sample}

The study was planned in a cross-sectional design. We aimed to include at least a total of 200 participants and for each item at least five participants, as suggested for psychometric studies, to represent the study population and all body systems related with exercise, including the neurological, immunological, and gastroenterological systems [8,9]. The participants of the study, target population of the instrument for primary care usage, were approached in the primary care offices. Questionnaires of participants responding "Yes" to at least one out of the first seven items were included in the evaluation. Twenty-five cases with some missing data were excluded.

\section{The Physical Activity Readiness Questionnaire for Everyone}

The original Physical Activity Readiness Questionnaire (PAR-Q) [10], updated in 1978 [11], 1992 [12], 2002 [13], 2011 [14], 2014 [15], and later in 2016 [16], is applied to yearly millions of people [17]. The test consists of seven preliminary questions + additional items 10 (41 with the subdomains) with dichotomous (Yes/No) answers, making a total of 48 items. People who answer "No" to all the first seven questions are regarded as able to become more physically active or engage in a fitness appraisal. If the respondent has marked "Yes" to one or more of the first seven questions, the decision is made after answering the remaining 41 questions [14]. Although we used the 2015 version of the instrument, there is a 2017 version available with minor modifications [18].

\section{Translation of the questionnaire into Turkish and content validity}

1. English-Turkish Translation: A collective Turkish text was produced after three consecutive meetings of four experts.

2. Piloting-revision-piloting: The Turkish text was applied to 20 participants. Reading and comprehension of the instrument were assured by the same team, substituting medical jargon with a public language or giving explanations in brackets.

3. Accordingly, the following explanations were added within brackets: chronic (continuous), pre-diabetes (hidden sugar), dementia (senility), chronic obstructive lung disease (COPD), spinal cord (backbone), tetraplegia (paralysis of all four limbs), paraplegia (loss of motor function of the lower extremities), and epilepsy (convulsion). The terms "exercise" instead of "physical activity," "tension" instead of "blood pressure," "heart and vessels" instead of "cardiovascular," and "used in case of urgent need" instead of "rescue medication" were preferred.

4. After the revision of the problematic words, their reading and comprehension were assured by re-applying to 20 participants.

5. Turkish-English Back Translation: The back translation was done by an English translator from the department of foreign languages. The study team compared the original and back-translated texts and decided on their conformity.

The Turkish version of the study instrument called "Herkes için Egzersize Hazırbulunuşluk Anketi" (EGZ-A+) is attached to this report. 


\section{Data collection}

The data were collected from December 2016 to January 2017 from patients who applied to the family medicine polyclinics and were able to fill the EGZ-A+ test. Additional data on age, gender, height, weight, marital status, educational status, place of residence, blood pressure status, smoking status, and diabetes status were collected from the participants. Body mass index (BMI) was calculated using height and weight $\left(\mathrm{kg} / \mathrm{m}^{2}\right)$.

\section{Test/Re--Test Reliability}

The test/retest reliability analysis was conducted in a subgroup of 103 subjects. The participants were asked to respond to the EGZ-A+ test twice with a one-month interval. Each of the 48 questions was coded as "0" if marked as "No" and "1" when marked as "Yes". All responses of each participant were added together. The test/retest scores obtained were analyzed using the Spearman rank correlation.

\section{Ethical considerations}

The study was implemented after the approval of the Çanakkale Onsekiz Mart University Ethical Board for Clinical Studies, dated 20.01.2016 (reg. 01-02). Written informed consent was taken from all participants.

\section{Statistical Analysis}

The data were analyzed using SPSS for Windows (version 18.0) and Microsoft Excel 2010. The results were presented as n, \%, mean, and standard deviation (SD). Reliability analysis was done using the Spearman rank correlation coefficient. A p value of less than 0.05 was accepted as significant.

\section{Results}

Basic characteristics of the participants are given in Table 1. Mean $( \pm \mathrm{SD})$ age and body mass index of the participants were $48.0 \pm 16.1$ and $27.9 \pm 5.9$, respectively. Of the participants, $58.6 \%(n=178)$ were males, the majority $(36.8 \% ; n=112)$ with primary school education. $67.7 \%(n=205)$ were married and 52.6\% ( $\mathrm{n}=159)$ living in urban settlings. Hypertension, diabetes, and smoking frequencies were $32.2 \%(\mathrm{n}=98), 26.0 \%(\mathrm{n}=79)$, and $37.8 \%(\mathrm{n}=115)$, respectively.

Distributions of the participant responses to the first seven questions of the EGZ-A+ test are given in Table 2. The highest "Yes" responses were to the questions "Are you currently taking prescribed medications for a chronic medical condition?" and "Have you ever been diagnosed with another chronic medical condition (other than heart disease or high blood pressure)?" with aggregations of 69.4\% (n=211) and 68.4\% (n=208), respectively. While the question "Has your doctor ever said that you should only do medically supervised physical activity?" received only $12.2 \%$ $(\mathrm{n}=37)$ "Yes" response.

Distributions of the medical conditions reported by the participants are given in Figure 1. The most common three medical conditions by order of frequency were of cardiovascular $(26.6 \% ; \mathrm{n}=81)$, physical medicine $(21.7 \% ; \mathrm{n}=66)$, and endocrine $(20.1 \% ; \mathrm{n}=61)$ types.

103 participants completed the EGZ-A+ on repeat occasions (separated by a one-month period) with a remarkable correlation value $(\mathrm{r}=0.87$, $\mathrm{p}<0.001)$.

\section{Discussion}

The study was conducted with an adequate sample, and the PAR-Q+ instrument was adapted into Turkish for the first time. With the increase of awareness on this tool in Turkey, we expect people to utilize it in increasing frequencies. Medical professionals, especially the family physicians may use the instrument when consulting their populations. In this way, physical activity may be promoted, and unnecessary referrals can be prevented. As a matter of fact, Warburton et al. have demonstrated only a $1 \%$ unnecessary referral with the use of the PAR-Q+ [14]. With the use of this scale as a standard, it will also contribute to overcoming the barriers to physical activity, especially for those patients with chronic illnesses. According to the "Chronic Disease Risk Factor Survey" conducted by the Turkish Ministry of Health in 2011, 87\% of women and 77\% of men had no adequate physical activity [19]. This is a serious finding suggesting a sedentary lifestyle among the Turkish population.

According to the World Health Organization, adults with a BMI of 25.0-29.9 are defined as "overweight" [20]. Accordingly, the mean BMI of our participants should be categorized as "overweight", which is quite high. This, in turn, reflects the participants' physical activity needs. Also, hypertension and diabetes rates of our participants were very high. We believe, one reason for this may be the affiliation of the family practice center with the tertiary level teaching hospital. Another reason may be the inclusion of only selected cases with at least one positive response to the first seven questions, which increased the possibility of sick participants. Although this context may not suite the low prevalence medicine, it shows the need of this population to join some physical activity program. 


\begin{tabular}{|c|c|c|c|}
\hline \multirow{2}{*}{\multicolumn{2}{|c|}{ Age (yrs.) }} & Mean / n & $\mathrm{SD} / \%$ \\
\hline & & 48.0 & 16.1 \\
\hline \multicolumn{2}{|l|}{ Height $(\mathrm{cm})$} & 170.6 & 84.7 \\
\hline \multicolumn{2}{|l|}{ Weight (kg) } & 76.3 & 15.7 \\
\hline \multicolumn{2}{|l|}{$\mathrm{BMI}\left(\mathrm{kg} / \mathrm{m}^{2}\right)$} & 27.9 & 5.9 \\
\hline \multicolumn{2}{|c|}{ Systolic Blood Pressure } & 125.0 & 17.7 \\
\hline \multirow[t]{2}{*}{ Gender } & Female & 178 & 58.6 \\
\hline & Male & 126 & 41.4 \\
\hline \multirow[t]{6}{*}{ Education } & Literate & 11 & 3.6 \\
\hline & Primary & 112 & 36.8 \\
\hline & Secondary & 22 & 7.3 \\
\hline & College & 46 & 15.1 \\
\hline & University & 96 & 31.6 \\
\hline & Doctorate & 17 & 5.6 \\
\hline \multirow[t]{3}{*}{ Marital Status } & Single & 65 & 21.4 \\
\hline & Married & 206 & 67.7 \\
\hline & Divorced/widow & 33 & 10.9 \\
\hline \multirow[t]{9}{*}{ Occupation } & Unemployed & 13 & 4.3 \\
\hline & Employee & 33 & 10.9 \\
\hline & Merchant & 11 & 3.6 \\
\hline & Student & 43 & 14.1 \\
\hline & Officer & 34 & 11.2 \\
\hline & Farmer & 8 & 2.6 \\
\hline & Housewife & 84 & 27.6 \\
\hline & Retired & 69 & 22.7 \\
\hline & Other & 9 & 3.0 \\
\hline \multirow[t]{4}{*}{ Region } & Rural village & 47 & 15.5 \\
\hline & Rural burg & 15 & 4.9 \\
\hline & Urban town & 82 & 27.0 \\
\hline & Urban city & 159 & 52.6 \\
\hline \multirow{2}{*}{$\begin{array}{l}\text { Hypertension } \\
\text { Medication }\end{array}$} & No & 206 & 67.8 \\
\hline & Yes & 98 & 32.2 \\
\hline \multirow[t]{2}{*}{ Smoking } & No & 189 & 62.2 \\
\hline & Yes & 115 & 37.8 \\
\hline \multirow[t]{2}{*}{ Diabetes mellitus } & No & 225 & 74.0 \\
\hline & Yes & 79 & 26.0 \\
\hline
\end{tabular}


Table 2. Number and percentage of respondents answering "Yes" or "No" to the EGZ-A+ $(\mathrm{n}=304)$.

\begin{tabular}{|c|c|c|c|c|c|}
\hline \multirow[b]{2}{*}{ No } & & \multicolumn{2}{|c|}{ Yes } & \multicolumn{2}{|c|}{ No } \\
\hline & & $\mathrm{n}$ & $\%$ & $\mathrm{n}$ & $\%$ \\
\hline 1 & Has your doctor ever said that you have a heart condition OR high blood pressure? & 140 & 46.1 & 164 & 53.9 \\
\hline 2 & $\begin{array}{l}\text { Do you feel pain in your chest at rest, during your daily activities of living OR when you do physical } \\
\text { activity? }\end{array}$ & 95 & 31.3 & 209 & 68.8 \\
\hline 3 & Do you lose balance because of dizziness OR have you lost consciousness in the last 12 months? & 95 & 31.3 & 209 & 68.8 \\
\hline 4 & $\begin{array}{l}\text { Have you ever been diagnosed with another chronic medical condition (other than heart disease or high } \\
\text { blood pressure)? }\end{array}$ & 208 & 68.4 & 96 & 31.6 \\
\hline 5 & Are you currently taking prescribed medications for a chronic medical condition? & 211 & 69.4 & 93 & 30.6 \\
\hline 6 & Do you have a bone or joint problem that could be made worse by becoming more physically active? & 119 & 39.1 & 185 & 60.9 \\
\hline 7 & Has your doctor ever said that you should only do medically supervised physical activity? & 37 & 12.2 & 267 & 87.8 \\
\hline
\end{tabular}

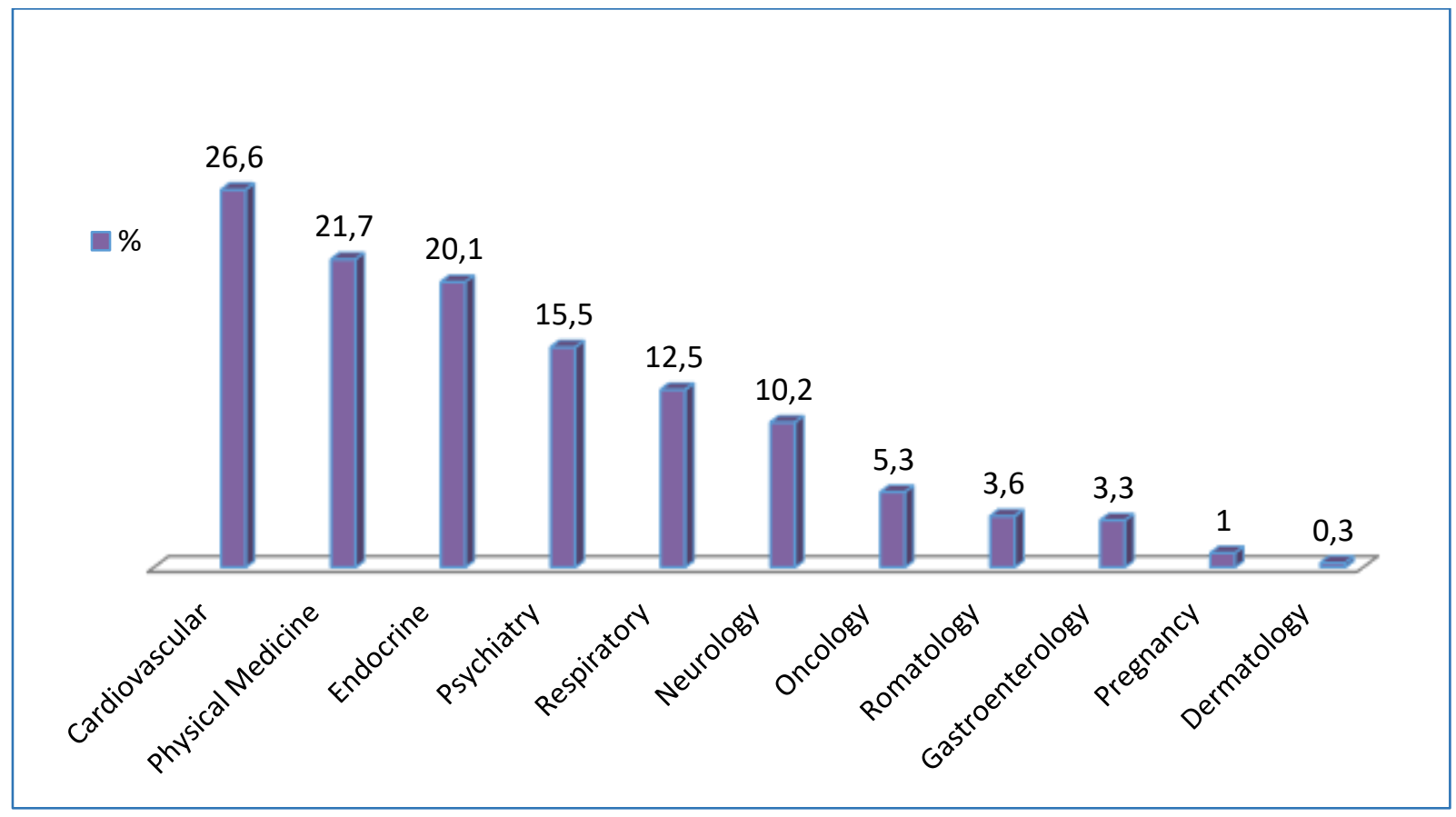

Figure 1: Frequency of self-reported medical conditions $(\mathrm{n}=304)$.

ACSM recently updated recommendations for pre-exercise evaluation [21]. The ACSM guidelines have replaced risk factor assessment, with an algorithm that first stratifies based on current physical activity level, then by the presence of chronic disease, and/or signs and symptoms of chronic disease, and last by desired exercise intensity. It was reported that $63 \%$ of family physicians are aware of guidelines for issuing pre-exercise certificates [3].

Our participants reported having ten different medical conditions. Each of the cardiovascular, physical medicine, and endocrine diseases had a frequency of above $20 \%$, a significantly high proportion. Regular physical activity decreases the risks of high blood pressure as well as cardiovascular diseases, diabetes, breast and colon cancers, and depression. There is a direct relationship between physical activity and the reductions in the risks of coronary heart disease, stroke, and diabetes. It is indicated that moderate physical activity of 150 minutes every week reduces ischemic heart disease risk by about $30 \%$, diabetes risk by $27 \%$, and breast and colon cancer risk by $21-25 \%$. Physical activity also reduces the chances of stroke, hypertension, and depression [22]. Habitual physical activity is associated with a reduced risk for over 25 chronic conditions and premature mortality [23-27]. Moderate intensity physical activity on most days of the week is of benefit for most patients with chronic conditions [28]. Warburton et al. have suggested physical activity for many conditions including cardiovascular disease, arthritis, osteoporosis, 
spinal cord injury, pregnancy, cancers, metabolic conditions, diabetes, asthma, and stroke. These suggestions should serve as a standard for health professionals planning to prescribe exercise for their patients [28].

Some criticisms have been made for the PAR-Q. For instance, the original authors confirm that the PAR-Q is purposely conservative [29]. This, in turn, may lead to many false positive results, causing unnecessary referrals [30]. Also, the age restrictions of the PAR-Q (i.e., 15 to 69 years) create an unnecessary barrier to physical activity participation for children and seniors. On the other hand, the PAR-Q can be regarded as a barrier for individuals who need increased physical activity the most, such as those living with chronic medical conditions [14,31]. Moreover, physicians commonly complain that the PARmed-X is too long, is very difficult to use, and is not evidence-based [29].

Healthcare providers, as well as health managers and policymakers, should take all measures to promote exercise. These efforts should include the utilization of exercise readiness tools such as the EGZ-A+. Our findings support the utility and potential of the EGZ-A+ risk stratification and preparticipation clearance strategy collectively.

\section{Conclusion}

The PAR-Q, or physical activity readiness questionnaire, is a simple self-screening tool that can and should be used by Turkish individuals as well as health professionals who are planning to start or guide an exercise program. This study has demonstrated safe usage of the Turkish adaptation of the PAR-Q+ (the EGZ-A+) instrument. We believe that this tool should become widely used by family physicians.

\section{Limitations of the study}

Having included only participants responding "Yes" to at least one of the first seven instrument questions is restraining the study from analyzing sensitivity and specificity of the survey in detecting certain medical conditions. Also, we did not include a gold-standard test and did not check for criterion reliability.

\section{Acknowledgements}

I would like to express my deep gratitude to Murat Tekin, Aysegul Uludag, and Erkan Melih Sahin, my expert team, for their co-operation in the producing of Turkish text.

\section{References}

1. WHO. Global recommendations on physical activity for health. Geneva World Health Organization 2010:60. doi: http://dx.doi.org/10.1080/11026480410034349

2. Barkley LC, Axeş MJ. Screening for sport and exercise participation. In: Kolt G, Lynn S-M, editors. Phys. Ther. Sport Exerc. 2nd ed., Edinburgh: Churchill Livingstone; 2007, p. 190-191.

3. Joy EA, Pescatello LS. Pre-exercise screening: Role of the primary care physician. Isr J Health Policy Res 2016;5. doi: http://dx.doi.org/10.1186/s13584-016-0089-0

4. Warburton DER, Gledhill N, Jamnik VK, et al. The Physical Activity Readiness Questionnaire for Everyone (PAR---Q+) and electronic Physical Activity Readiness Medical Examination (ePARmed---X+): Summary of Consensus Panel recommendations. Heal Fit J Canada 2011;4:26-37.

5. Balady GJ, Chaitman B, Driscoll D, et al. Recommendations for cardiovascular screening, staffing, and emergency policies at health/fitness facilities. Circulation 1998;97:2283-2293. doi: http://dx.doi.org/10.1161/01.CIR.97.22.2283

6. Riebe D, Franklin BA, Thompson PD, et al. Updating ACSM's recommendations for exercise preparticipation health screening. Med Sci Sports Exerc 2015;47:2473-2479. doi: http://dx.doi.org/10.1249/MSS.0000000000000664

7. Warburton DER, Bredin SSD, Jamnik VK, Gledhill N. International launch of the PAR-Q+ and ePARmed-X+ validation of the PAR-Q+ and ePARmed-X+. Heal Fit J Canada 2011;4:38-46.

8. Gorsuch RL. Factor analysis. USA: W. B. Saunders Company; 1974.

9. Comrey AL. A First Course in Factor Analysis. USA: Academic Press; 1973.

10. Chisholm DM, Collis ML, Kulak LL, Davenport W, Gruber N. Physical activity readiness. B C Med J 1975;17:375-378.

11. Chisholm DM, Collis ML, Kulak LL, et al. PAR-Q validation report: the evaluation of a self-administered pre-exercise screening questionnaire for adults. Victoria Canada BC Minist Heal Heal Welf 1978.

12. Thomas S, Reading J, Shephard RJ. Revision of the Physical Activity Readiness Questionnaire (PAR-Q). Can J Sport Sci 1992;17:338-345.

13. Gledhill N. The revised PAR-Q. Toronto, Ontario: York University; 2002.

14. Warburton DER, Jamnik VK, Bredin SSD, Gledhill N. The Physical Activity Readiness Questionnaire for Everyone (PAR-Q+) and Electronic Physical Activity Readiness Medical Examination (ePARmed-X+). Heal Fit J Canada 2011;4:3-17.

15. Warburton DER, Jamnik V, Bredin SSD, Gledhill N. Physical Activity Readiness Questionnaire for Everyone (PAR-Q+) and electronic Physical Activity Readiness Medical Examination (ePARmed-X+). Heal Fit J Canada 2014;7:80-83.

16. The New PAR-Q+ and ePARmed-X+: official website. PAR-Q+ Collab 2018. http://eparmedx.com/ (accessed January 31, 2018). 
17. Warburton DER, Jamnik VK, Bredin SSD, Gledhill N. The ePARmed-X+ Physician Clearance Follow-up. Heal Fit J Canada 2014;7:35-38.

18. 2017 PAR-Q+. PAR-Q+ Collaboration. http://eparmedx.com/wp-content/uploads/2013/03/January2017PARQPlusUpdated.pdf (accessed January 31, 2018).

19. Ünal B, Ergör G. Türkiye kronik hastalıklar ve risk faktörleri sıklığı çalışması. Ankara: T.C. Sağlık Bakanlığı; 2013.

20. Barba C, Cavalli-Sforza T, Cutter J, et al. Appropriate body-mass index for Asian populations and its implications for policy and intervention strategies. Lancet 2004;363:157-163. doi: http://dx.doi.org/10.1016/S0140-6736(03)15268-3

21. Lupash E, editor. ACSM's guidelines for exercise testing and prescription. Lippincott Williams \& Wilkins; 2013.

22. World Health Organization. Global status report on noncommunicable diseases 2010. Reprinted 2011.

23. Warburton DE, Charlesworth S, Ivey A, Nettlefold L, Bredin SS. A systematic review of the evidence for Canada's Physical Activity Guidelines for Adults. Int J Behav Nutr Phys Act 2010;7:39. doi: http://dx.doi.org/10.1186/1479-5868-7-39

24. Warburton DE, Glendhill N, Quinney A. The effects of changes in musculoskeletal fitness on health. Can J Appl Physiol 2001;26:161-216. doi: https://doi.org/10.1139/h01-012

25. Blair SN, Kohl HW 3rd, Paffenbarger RSJ, Clark DG, Cooper KH, Gibbons LW. Physical fitness and all-cause mortality. A prospective study of healthy men and women. JAMA 1989;262:2395-2401. doi: http://dx.doi.org/10.1001/jama.1989.03430170057028

26. Blair SN, Brodney S. Effects of physical inactivity and obesity on morbidity and mortality: current evidence and research issues. Med Sci Sports Exerc 1999;31:S646-62.

27. Chodzko-Zajko WJ, Proctor DN, Fiatarone Singh MA, et al. American College of Sports Medicine position stand. Exercise and physical activity for older adults. Med Sci Sports Exerc 2009;41:1510-1530. doi: http://dx.doi.org/10.1249/MSS.0b013e3181a0c95c

28. Mark R, Rhodes RE, Warburton DER, Cep C, Me CC-, Bredin SSD. Heal Fit J Canada 2008;1:14-24.

29. Bredin SSD, Gledhill N, Jamnik VK, Warburton DER. PAR-Q+ and ePARmed-X+: New risk stratification and physical activity clearance strategy for physicians and patients alike. Can Fam Physician 2013;59:273-277.

30. Warburton DER, Jamnik VK, Bredin SSD, et al. Executive Summary The 2011 Physical Activity Readiness Questionnaire for Everyone (PAR--Q+) and the Electronic Physical Activity Readiness Medical Examination (ePARmed--X+). Heal Fit J Canada 2011;4:24-25.

31. Jamnik VK, Warburton DER, Makarski J, et al. Enhancing the effectiveness of clearance for physical activity participation: background and overall process. Appl Physiol Nutr Metab 2011;36 Suppl 1:S3-13. doi: http://dx.doi.org/10.1139/h11-044 


\section{EGZ-A+}

\section{Herkes için Egzersize Hazırbulunuşluk Anketi}

Düzenli egzersizin sağlığa yararları açıkça bilinmektedir; herkes her gün egzersiz yapmalıdır. Egzersize başlamak çoğu insan için oldukça güvenlidir. Bu anket size daha aktif egzersize başlamadan önce doktorunuzun veya egzersiz uzmanının önerilerini almaya gerek olup olmadığını söyleyecektir.

GENEL SAĞLIK SORULARI

Lütfen aşağıdaki 7 soruyu dikkatlice okuyun ve her birini dürüstçe yanıtlayın: EVET veya HAYIR kutucuğunu işaretleyin.

1) Doktorunuz size hiç kalp hastalı̆̆ınız olduğunu $\square$ VEYA tansiyonunuzun yüksek olduğunu $\square$ söyledi mi?

2) Dinlenirken, günlük yaşantınız içerisinde VEYA egzersiz yaparken göğüs ağrısı hissettiniz mi?

3) Son 12 ay içinde baş dönmesi sebebiyle dengenizi yitirdiğiniz VEYA bilincinizi kaybettiğiniz (bayıldığınız) oldu mu?

Eğer baş dönmeniz (ağır egzersiz sırasında olsa bile) fazla soluklanmayla ilişkiliyse lütfen HAYIR'ı işaretleyiniz.

4) Bugüne kadar size hiç (kalp hastalığı ve yüksek tansiyon hariç) kronik (sürekli) bir hastalık tanısı konuldu mu? LÜTFEN HASTALIKLARI BURAYA YAZINIZ:

5) Halen kronik (sürekli) bir hastalık için reçeteli ilaç kullanıyor musunuz? LÜTFEN HASTALIKLARI VE İLAÇLARI BURAYA YAZINIZ:

6) Halen (ya da son 12 ay içinde) egzersizle kötüleşebilecek kemik, eklem veya yumuşak doku (kas, bağ veya kiriş) sorununuz var mı? Geçmişte var olan bir sorununuz, şu anda egzersiz yapmanızı kısıtlamayacaksa lütfen HAYIR'1 işaretleyiniz. LÜTFEN HASTALIKLARI BURAYA YAZINIZ:

7) Doktorunuz size hiç egzersizi sadece tıbbi gözetim altındayken yapabileceğinizi söyledi mi? 


\section{EGZ-A+}

TIBBİ DURUMUNUZLA ILGILII TAMAMLAYICI SORULAR

\section{Eklem Hastalığı, Kemik Erimesi, Sırt veya Bel Rahatsızlığınız var mı? Varsa} aşağıdaki soruları yanıtlayın, Yok $\square$ ise 2. soruya geçin.

1a.İlaçlarla veya doktorun verdiği diğer tedaviler ile rahatsızlığınızla baş etmekte zorlanıyor musunuz? (Şu an ilaç veya başka tedavi almıorsanız HAYIR yanıtlayın)

\section{EVET $\square \quad$ HAYIR $\square$}

1b. Ağrıya sebep olan eklem rahatsızlıkları, yakın zamandaki kırık, kemik erimesi veya kansere bağlı bir kırık, omur kayması (ör. spondilolistesis) ve/veya spondilolisis/pars defekti (omurganın arkasındaki kemik halkada çatlak) var mı?

EVET $\square$ HAYIR $\square$ 1c. Düzenli olarak 3 aydan uzun süreyle steroid (kortizon vb.) iğnesi veya steroid hap1 kullandınız mı?

EVET $\square \quad$ HAYIR $\square$

2. Herhangi bir çeşit Kanseriniz var mı? Varsa aşağıdaki soruları yanıtlayın, Yok $\square$ ise 3 . soruya geçin.

2a. Kanser tanınız şu tiplerden biri mi: akciğer/bronş, multipl miyelom (plazma hücreli kanser), baş ve boyun?

EVET $\square \quad$ HAYIR $\square$

2b. Halen kanser tedavisi alıyor musunuz (kemoterapi veya radyoterapi gibi)?

EVET $\square$

HAYIR $\square$ 


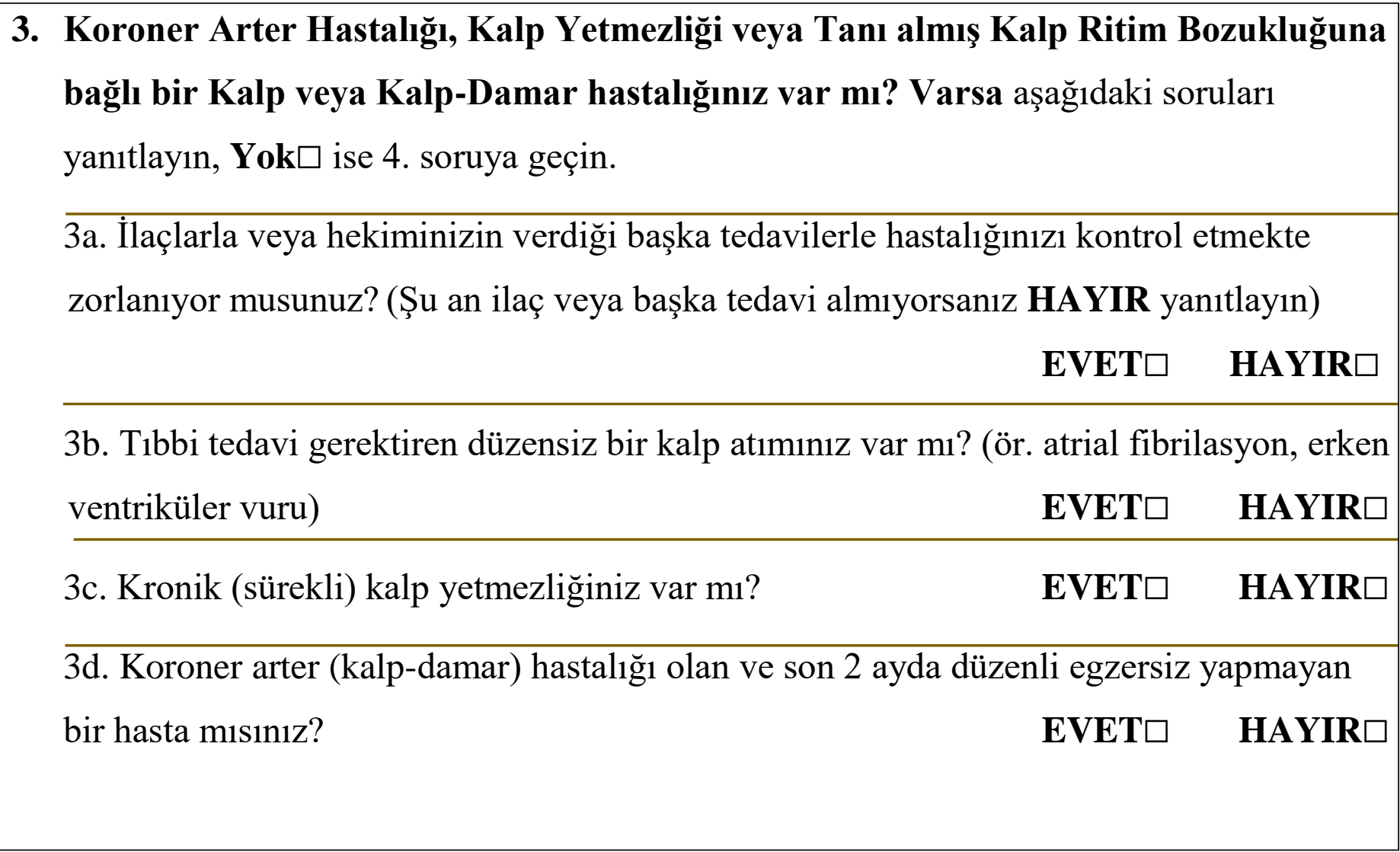

4. Yüksek Tansiyonunuz var mı? Varsa aşağıdaki soruları yanıtlayın, Yok $\square$ ise 5. soruya geçin.

4a. İlaçlarla veya hekiminizin verdiği başka tedavilerle hastalığınızı kontrol etmekte zorlanıyor musunuz? (Halen ilaç veya başka tedavi almıyorsanız HAYIR yanıtlayın)

EVET $\square \quad$ HAYIR $\square$

4b. İstirahatteki tansiyonunuz ilaçlı ya da ilaçsız 160/90 mmHg 'ye eşit ya da üzerinde mi? (İstirahatteki tansiyonunuzu bilmiyorsanız EVET yanıtlayın) EVET $\square \quad$ HAYIR $\square$ 


\section{Tip-1 Diyabet, Tip-2 Diyabet veya Pre-Diyabet (gizli şeker) gibi herhangi bir} metabolik hastalığınız var mı? Varsa aşağıdaki soruları yanıtlayın, Yok $\square$ ise 6 . soruya geçin.

5a. Yiyecekler, ilaçlar veya doktorun verdiği diğer tedavilerle kan şeker düzeyinizi ayarlamakta sıklıkla zorlanıyor musunuz?

EVET $\square \quad$ HAYIR $\square$

5b. Günlük yaşantınız esnasında ve/veya egzersizi takiben sıklıkla düşük kan şekeri (hipoglisemi) 'nin belirti veya bulgularını yaşar mısınız? Hipogliseminin işaretleri; titreme, sinirlilik, beklenmedik huzursuzluk, anormal terleme, baş dönmesi ya da göz kararması, kafa karışıklığı, konuşma güçlüğü, halsizlik ve uyuklama olabilir.

EVET $\square \quad$ HAYIR $\square$

5c. Kalp veya damar hastalığı ve/veya gözlerinizi, böbreklerinizi etkileyen komplikasyonlar VEYA ayak ve ayak parmaklarında his değişikliği gibi diyabet komplikasyonlarının belirti ve bulgularından herhangi biri var mı? EVET $\square$ HAYIR $\square$

5d. Başka metabolik hastalığınız var mı (mevcut gebeliğe bağlı diyabet, kronik [sürekli] böbrek yetmezliği veya karaciğer sorunları gibi)?

EVET $\square$ HAYIR $\square$ 5e. Yakın zamanda sizin için alışılmadık şekilde yüksek (veya ağır) şiddette egzersize başlamayı planlıyor musunuz? EVET $\square$ HAYIR $\square$

6. Alzheimer, Demans (bunama), Depresyon, Anksiyete Bozukluğu, Yeme Bozukluğu, Psikotik Bozukluk, Zihinsel Engellilik, Down Sendromu gibi bir Ruh Sağlı̆̆ı Sorununuz veya Öğrenme Güçlüğünüz var mı? Herhangi biri Varsa aşağıdaki soruları yanıtlayın, Yok $\square$ ise 7. soruya geçin.

6a. İlaçlarla veya hekiminizin verdiği başka tedavilerle hastalığınızı kontrol etmekte zorlanıyor musunuz? (Halen ilaç veya başka tedavi almıyorsanız HAYIR yanıtlayın)

EVET $\square \quad$ HAYIR $\square$

6b. Yukarıdaki hastalıklarla birlikte sinirleri veya kasları etkileyen sirt-bel rahatsızlığınız var mı?

EVET $\square$ HAYIR $\square$ 
7. Kronik Obstrüktif Akciğer Hastalığı (KOAH), Astım veya Pulmoner Hipertansiyon gibi solunum hastalığınız var mı? Varsa aşağıdaki soruları yanıtlayın, Yok $\square$ ise 8 . soruya geçin.

7a. İlaçlarla veya hekiminizin verdiği başka tedavilerle hastalığınızı kontrol etmekte zorlanıyor musunuz? (Halen ilaç veya başka tedavi almıyorsanız HAYIR yanıtlayın)

EVET $\square \quad$ HAYIR $\square$

7b. Doktorunuz size hiç istirahat veya egzersiz sırasında kan oksijen düzeyinizin düşük olduğunu ve/veya takviye oksijen tedavisine ihtiyaç duyduğunuzu söyledi mi?

EVET $\square \quad$ HAYIR $\square$

7c. Astımlıysanız; halen göğüs sıkışması, hırıltılı solunum, nefes darlığı, inatçı öksürük (haftada 2 günden fazla) şikâyetleriniz var mı, ya da geçen hafta ani nefes sıkışmasında alınacak ilacı iki kezden fazla kullandınız mı?

EVET $\square \quad$ HAYIR $\square$

7d. Doktorunuz size hiç akciğerlerinizin kan damarlarında yüksek tansiyonunuz olduğunu söyledi mi?

EVET $\square$ HAYIR $\square$

8. Spinal Kord (Omurga) yaralanmasına bağlı Tetrapleji (Her iki kol ve bacağın felci) veya Parapleji (Belden aşağı felç) var mı? Varsa aşağıdaki soruları yanıtlayın, Yok $\square$ ise 9. soruya geçin.

8a. İlaçlarla veya hekiminizin verdiği başka tedavilerle hastalığınızı kontrol etmekte zorlanıyor musunuz? (Halen ilaç veya başka tedavi almıyorsanız HAYIR yanıtlayın)

EVET $\square \quad$ HAYIR $\square$

8b. Sıklıkla baş dönmesi, göz kararması ve/veya baygınlığa sebep olacak kadar önemli istirahat kan basıncı düşüklüğü olur mu?

EVET $\square \quad$ HAYIR $\square$

8c.Doktorunuz size ani yükssek tansiyon atakları (Otonomik Disrefleksi) yaşadığınızı belirtti mi?

EVET $\square \quad$ HAYIR $\square$ 
9. İnme 'ye bağlı Geçici İskemik Atak veya Serebrovasküler Olay geçirdiniz mi?

Geçirdiyseniz aşağıdaki soruları yanıtlayın, Geçirmediyseniz $\square$ 10. soruya geçin.

9a. Ilaçlarla veya hekiminizin verdiği başka tedavilerle hastalığınızı kontrol etmekte zorlanıyor musunuz? (Halen ilaç veya başka tedavi almıyorsanız HAYIR yanıtlayın)

EVET $\square \quad$ HAYIR $\square$

9b. Yürüyüş veya hareketlerinizde herhangi bir problem var mı？ EVET $\square \quad$ HAYIR $\square$

9c. Son 6 ayda sinir veya kaslarınızda felç veya zayıflık yaşadınız mı?

EVET $\square$

HAYIR $\square$

10. Yukarıda listelenmemiş başka herhangi tıbbi durumunuz var mı, veya iki ya da daha fazla tıbbi hastalığınız var mı? Varsa aşağıdaki soruları yanıtlayın, Yok $\square$ ise son sayfadaki önerileri okuyun.

10a. Son 12 ayda kafa travması sonucunda kendinden geçme, baygınlık veya bilinç kaybı yaşadınız mı VEYA son 12 ayda beyin sarsıntısı tanısı aldınız mı? EVET $\square \quad$ HAYIR $\square$ 10b. Listede yer almayan tıbbi durumunuz var mı (epilepsi [sara], nörolojik hastalıklar, böbrek problemleri gibi)?

EVET $\square$ HAYIR $\square$

10c. Şu an iki veya daha fazla tıbbi hastalığınız var mı?

EVET $\square$ HAYIR $\square$

\section{LÜTFEN TIBBİ HASTALIKLARINIZI VE İLIŞKILII HER ÍLACI YAZINIZ:}

